DOI: 10.12731/2227-930X-2020-3-18-29

UDC $332+327+910$

\title{
THE ARCTIC REGIONAL SECURITY: A SCIENTOMETRIC ANALYSIS OF INFORMATION ARRAYS IN DATABASES WEB OF SCIENCE AND SCHOLAR SIBIRICA
}

\section{Rykova $V . V$.}

The article traces main trends of the scientific research development on security in the Arctic region using the international database Web of Science by Thomson Reuters Co and the regional database Scholar Sibirica generated by the State Public Scientific Technological Library of the Siberian Branch of the Russian Academy of Sciences. Using a scientometric analysis and analytical tools of DBs, the author shows countries, institutions and organizations that study this problem, as well as funds financing them; names productive periodicals and authors with high publication activity; presents monographs and dissertation studies of recent years; reveals the main research areas. In conclusion, the author notes that the study of the safety at the Arctic territories is an urgent problem for the entire world society, not only for the northern countries; the above-mentioned DBs should be regarded as an information base for further study of the Arctic security.

Objective - to carry on a scientometric analysis of information arrays (IA) devoted to studying the Arctic region security.

Methods: scientometric analysis.

Results: countries, institutions and organizations that study this problem are represented, as well as funds financing them; productive periodicals and authors with high publication activity are designated; monographs and dissertation studies of recent years are shown; the main research fields are revealed.

Practical implications: the study should be used as an information base for further research of scientists and specialists on various aspects of the Arctic region security. 
Keywords: security; Arctic; research information support; $D B$ Web of Sciences; DB Scholar Sibirica; scientometric analysis.

\section{БЕЗОПАСНОСТЬ АРКТИЧЕСКОГО РЕГИОНА: НАУКОМЕТРИЧЕСКИЙ АНАЛИЗ ИНФОРМАЦИОННЫХ МАССИВОВ МЕЖДУНАРОДНОЙ И РЕГИОНАЛЬНОЙ БАЗ ДАННЫХ}

\section{Рыкова В.В.}

В статье прослежены тренды развития научных исследований по теме «Безопасность Арктического региона» с использованием баз данных - межуднародной Web of Science (компании Thomson Reuters) и региональной Научная Сибирика (собственной генераичии Государственной публичной научно-технической библиотеки Сибирского отделения Российской академии наук). В базах данных с использованием булевых операторов и ключевых слов вылвлены документальные массивы по теме, проведен их сравнительный наукометрический анализ. Аналитические сервисы баз данньх позволили назвать страны, учреждения и организачии, занимающиеся изучением данной проблемы, а также финансирующие их фонды. Определень наиболее продуктивные периодические издания и авторы с высокой публикационной активностью. Представлены научные мероприятия, проводимые по теме, монографии и диссертационные исследования последних лет. Показана тематическая структура информационных массивов. Отмечено, что изучение безопасности арктических территорий является актуальной проблемой всего мирового сообщества, а не только северных стран. Выменазванные базы данных могут служсть информачионной основой дальнейших исследований различных аспектов безопасности Арктического региона.

Цель - проведение наукометрического анализа информационных массивов, посвященных изучению безопасности Арктического региона. 
Методы: наукометрический анализ.

Результаты: представлены страны, учреждения и организации, которые изучают эту проблему, а также фонды, финансирующие их; обозначены продуктивные периодические издания и авторы с высокой публикаиионной активностью; показаны монографии и диссертационные исследования последних лет; выяялены основные направления исследований.

Область применения результатов: исследование могут служить информачионной основой дальнейших исследований ученых и специалистов по различным аспектам безопасности Арктического региона.

Ключевые слова: безопасность; Арктика; БД Web of Sciences; БД Научная Сибирика; наукометрический анализ.

\section{Introduction}

The Arctic has recently attracted the close attention of politicians, scientists, and experts as an important geostrategic region with significant reserves of natural resources, as well as a transport corridor that provides trade links between Europe and Asia. The imperfection of the legal framework has led to aggravation of territorial disputes in the region. Russia has adopted the State Program "Socio-economic development of the Arctic zone of the Russian Federation" until 2025 according with the Intergovernmental Panel on Climate Change recommendations, which provides creation of supporting regions in the Arctic for the territory of complex development, technological investigations and the resource base efficient use in the Russian Arctic zone and the Arctic ocean continental shelf. Decree of the President of the Russian Federation on 05.03.2020 No. 164 "On the State Policy Bases of the Russian Federation in the Arctic for the Period until 2035" defines foundations of the state policy of the Russian Federation Arctic regions [1]. In this regard, security issues in the Arctic are highlighted.

The article objective is to carry on a scientometric analysis of information arrays (IA) devoted to studying the Arctic region security. 


\section{Materials and methods}

To analyze researches on the security in the Arctic region two databases (DBs) were applied:

- Web of Science (WoS), the global scientific citation database of Thomson Reuters;

- Scientific Siberia, a regional database generated by the State Public Scientific and Technoloical Library of the Siberian Branch of the Russian Academy of Sciences (SPSL SB RAS), included a large thematic section "Problems of the North" that concentrates and systematizes bibliographic data on studying the complicated problems in the Arctic zone countries [2].

IAs have been selected of the mentioned above DBs using keywords and Boolean operators. The volume of IAs for the period 1990-2019 compiled over 900 documents in WoS, and more than 1,300 documents in Scholar Sibirica on February, 2020.

The specialists of the Department of Scinetific Bibliography have long tradition of scientometric analisis of documents flow in different research fields $[3,4]$.

A scientometric analysis of IAs of the international DB WoS by Thomson Reuters and a regional DB Scholar Sibirica of SPSL SB RAS' own generation includes:

1) revealing trends of scientific research development on the Arctic safety,

2) representing the countries and institutions involved in the problem study, as well as organizations funding the researches,

3) nominating the productive periodicals on the issue,

4) identifying authors with high publication activity,

5) pointing out importance of monographs and dissertations for recent years,

6) designating research topics.

\section{Study results}

The dynamics of IAs over a 30-year period is shown in the diagram (Fig. 1), where the growth in the publications amount is clearly 
visible, documents' number increase is especially noticeable the last decade. Editions of 2019 are still being transferred to the collections of the State Public Scientific Technological Library SB RAS, therefore the total number of documents in the DB Scholar Sibirica is expected to be significantly larger over the past few years. The interest of scientists and specialists to this problem is explained by the geopolitical competition of the polar states and the interest of non-Arctic states to develop the Arctic natural resources.

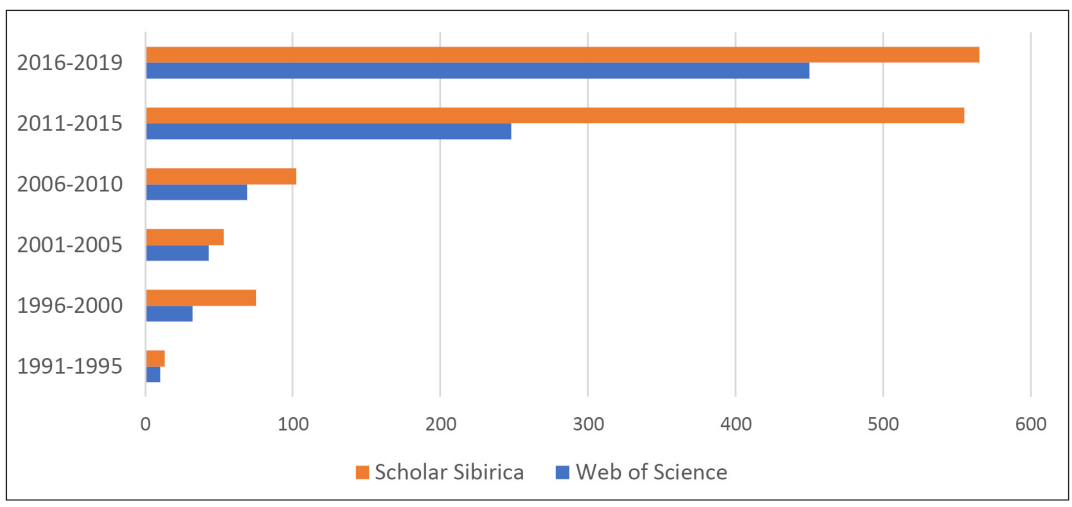

Fig. 1. IAs dynamics of DBs Web of Science and Scholar Sibirica

The documents distribution by language in DBs Web of Science and Scholar Sibirica is presented in Table. 1.

Table 1.

The linguistic structure of IAs in DB Web of Science and Scholar Sibirica

\begin{tabular}{|l|l|l|l|l|}
\hline \multicolumn{1}{|c|}{ Language } & \multicolumn{2}{c|}{ Web of Science } & \multicolumn{2}{c|}{ Scholar Sibirica } \\
\hline & Record number & $\%$ & Record number & $\%$ \\
\hline English & 856 & 93 & 47 & 3 \\
\hline Russian & 45 & 5 & 1318 & 96 \\
\hline Chinese & 5 & 0,5 & - & - \\
\hline German & 4 & 0,5 & - & - \\
\hline Others & 10 & 1 & 13 & 1 \\
\hline
\end{tabular}

In the language structure of WoS, the main language of publications is English ( $93 \%$ of documents), works in Russian amounted to 5\% (23 
documents), articles in Chinese and German together did not exceed $1 \%$ of IA. Another picture is observed inDB Scholar Sibirica, where Russian-language materials prevail accounting for $96 \%$ of IA, while English-language publications are few, their share does not exceed 3\%.

The analytical tools of DB WoS allow users to identify the participation of the scientific community representatives from different states, affiliations of scientists and specialists, funds financing research on a particular problem. In studying the Arctic security the first five positions are taken by “northern' countries: Canada, USA, Russia, Norway and Finland. As all these states have domains beyond the Arctic Circle, which resources development is a priority the last decade, they pay close attention to the aforementioned problem. A significant contribution to research the Arctic security issues is also made by scientists from Germany, Great Britain, China, Sweden and Denmark.

Among the organizations funding the Arctic safety investigations are the National Science Foundation of the USA, the Natural Sciences and Engineering Research Council of Canada, ArcticNet (a Network of Centers of Excellence in Canada, which brings together scientists and specialists in the field of health, natural and social sciences), and scientific foundations of Russia and China.

The Arctic security researchers are affiliated with different organizations. A significant contribution to the Arctic security study is made by employees of the Russian Academy of Sciences institutions, as well as teachers and specialists from U.S. universities in Alaska (University of Alaska System, University of Alaska Fairbanks), Norway (University of Tromso, Norwegian University of Science and Technology), Canada (McGill University, Memorial University of Newfoundland, Laval University, University of Ottawa), Finland (University of Lapland). Obviously, the publications share in WoS by Russian authors will increase, because, firstly, Russian journals are actively working to include scientific citation in the world's largest databases, and secondly, Russian authors more often are published in leading world English-language publications.

The IA type-specific structure of DBs WoS and Scholar Sibirica is not the same, Table 2 presents quantitative indicators of publications' 
typical composition, Fig. 2 demonstrates the ratio of different types of documents in DBs.

Table 2.

The distribution of document types in DBs

\begin{tabular}{|l|l|l|l|l|}
\hline \multicolumn{1}{|c|}{ Document type } & \multicolumn{2}{c|}{ Web of Science } & \multicolumn{2}{c|}{ Scholar Sibirica } \\
\hline & Record number & $\%$ & Record number & $\%$ \\
\hline Papers in periodicals & 710 & 77 & 462 & 34 \\
\hline Conference proceedings & 226 & 24 & 691 & 51 \\
\hline Monographs & 3 & 0 & 68 & 5 \\
\hline Works in scientific collections & 71 & 8 & 103 & 7 \\
\hline Others & 9 & 1 & 16 & 1 \\
\hline
\end{tabular}

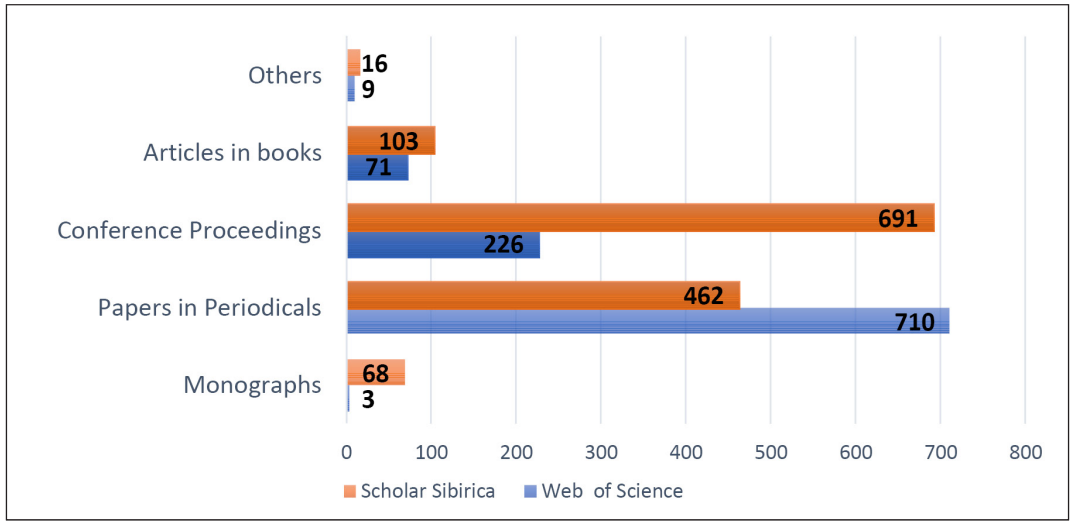

Fig. 2. The ratio of document types in DBs WoS and Scholar Sibirica

Articles in periodicals and conference proceedings dominate in the typical structure of documents (respectively $77 \%$ and $24 \%$ in WoS, $34 \%$ and $51 \%$ in Scholar Sibirica). Journals reflect the results of scientific research most quickly, Table 3 shows the Top-5 periodical titles on the number of articles devoted to studying the Far North region security problems.

Conference proceedings are no less important for the scholar community then periodicals, becuase there is an active exchange of information, discussion of topical issues, discussions on pressing issues during scientific meetings of various ranks. Most forums are held on an ongoing basis, together they form a half of IAs in DB Scholar Sibirica and a 
quarter one - in WoS (Table 2), the following of them should be noted: Conference on Ocean, Offshore and Arctic Engineering; Ocean IEEE conference; Problems of emergency situations prevention and liquidation in the Arctic region; Ensuring security during the implementation of large economic and infrastructure projects in the Arctic. Problems and solutions; Theory and practice of integrated marine research in the interests of the economy and security of the Russian North; Arctic: international cooperation, ecology and safety, innovative technologies and logistics, legal regulation, history and modernity, and others.

Table 3.

Top 5 productive periodicals on the subject in DBs WoS and Scholar Sibirica

\begin{tabular}{|c|l|c|l|c|}
\hline БД & \multicolumn{2}{|c|}{ Web of Science } & \multicolumn{2}{c|}{ Scholar Sibirica } \\
\hline № & \multicolumn{1}{|c|}{ Edition title, country } & $\begin{array}{c}\text { Paper } \\
\text { amount }\end{array}$ & \multicolumn{1}{c|}{ Edition title } & $\begin{array}{c}\text { Paper } \\
\text { amount }\end{array}$ \\
\hline 1 & $\begin{array}{l}\text { International Journal of Cir- } \\
\text { cumpolar Health (USA) }\end{array}$ & 31 & $\begin{array}{l}\text { Geopolitics and Security } \\
\text { (Russia) }\end{array}$ & 35 \\
\hline 2 & Polar Records (UK) & 22 & $\begin{array}{l}\text { National interests: priori- } \\
\text { ties and security (Russia) }\end{array}$ & 30 \\
\hline 3 & Arctic (Canada) & 21 & $\begin{array}{l}\text { Arctic: ecology and } \\
\text { safety (Russia) }\end{array}$ & 26 \\
\hline 4 & $\begin{array}{l}\text { Marine Intellectual Technol- } \\
\text { ogies (Russia) }\end{array}$ & 12 & Arctic News (Russia) & 21 \\
\hline 5 & Marine Policy (UK) & 12 & $\begin{array}{l}\text { Arctic and the North } \\
\text { (Russia) }\end{array}$ & 11 \\
\hline
\end{tabular}

A small group of monographic publications is the most important component of IAs, as they summarize the results of multiyear research by teams of scientists. The evidence of a significant amount of materials on the studied topic is editing over 20 monographs the last 4 years (2016-2019). As already noted, the books of the 2019 edition are not yet fully indexed in DBs, therefore their list included in the table is not complete. The monographs published in 2019 are devoted to the Arctic Council role at the northern affairs (Nord, 2019), the contested energy frontiers (Tynkkynen et al., 2019), security provision in the Russian Arctic zone (Ivchenko \& Shamatov, 2019).

The dissertation theses on various aspects of Arctic safety, demonstrates the growing interest of scientists in the aforementioned problems. Table 5 includes only titles of dissertation works defended in Rus- 
sia last years and entered DB Scholar Sibirica, since DB WoS doesn't represent such materials.

Table 5.

Dissertation works on the Arctic security defended in Russia for 2016-2019

\begin{tabular}{|c|l|l|}
\hline Year & \multicolumn{1}{|c|}{ Author } & \multicolumn{1}{c|}{ Title } \\
\hline 2016 & Masloboev A.V. & $\begin{array}{l}\text { Research and development of models and methods for } \\
\text { information support of regional security management } \\
\text { (a case of Murmansk Region) }\end{array}$ \\
\hline 2016 & Timofeev P.A. & $\begin{array}{l}\text { Scientific and methodological support to assess the hy- } \\
\text { drometeorological safety in the Arctic zone of the Rus- } \\
\text { sian Federation under the conditions of fuzzy information }\end{array}$ \\
\hline 2017 & Kravchuk A.A & $\begin{array}{l}\text { The main threats to the national security in the Arctic } \\
\text { of the Russian Federation and forming the state policy } \\
\text { to neutralize them }\end{array}$ \\
\hline 2018 & Sboychakova A.V. & $\begin{array}{l}\text { The Arctic Council role in shaping the environmental } \\
\text { security policy in the Arctic }\end{array}$ \\
\hline 2019 & Sergeeva V.V. & $\begin{array}{l}\text { The system development of the population socio-eco- } \\
\text { nomic security in the Arctic zone of the Republic of } \\
\text { Sakha (Yakutia) }\end{array}$ \\
\hline 2019 & Volodin D.A. & $\begin{array}{l}\text { Problems and prospects of Russian-Chinese coopera- } \\
\text { tion in the Arctic development }\end{array}$ \\
\hline $\begin{array}{l}\text { Canadian policy in the field of defense and interna- } \\
\text { tional security (1990s-2010s) }\end{array}$ \\
\hline
\end{tabular}

Among the authors with high publication activity (Scholar Sibirica), it is necessary to name employees of institutions of the Kola Scientific Center of the Russian Academy of Sciences, who are the authors of numerous monographs that address the security problems of the Arctic zone: A. V. Masloboev (Institute of Informatics and Mathematical modeling of technological), V. S. Selin, T. P. Skuf'ina, M. V. Ul'chenko (G.P. Luzin Institute of Economic Problems) and others.

The most productive authors of DB WoS are J.D. Ford (University of Leeds, UK) and A.A. Dudarev (Northwest Public Health Research Centre, Russia) engaged in studying save life of Arctic aboriginal communities and F. Khan (Memorial University of Newfoundland, Canada) dealing with safe navigation and drilling in the Arctic ocean).

Thematically, IAs of databases are structured identically, which indicates the general direction of research by scientists and specialists from different countries, which are aimed to solve the following problems: 
- geopolitics, national security and international relations,

- safe navigation along the Northern Sea Route,

- geotechnical safety of activity on regional natural and mineral resources exploitation,

- life safety of the population in the Arctic zone including the indigenous people of the North,

- environmental safety of the Arctic and sub-Arctic territories.

\section{Conclusion}

Summarizing the analysis results, it should be noted that studying the Arctic territories security is an urgent problem for the entire world community, and not only for the northern countries. The amount of information on the topic is steadily growing. Using a scientometric analysis and analytical tools of DBs, the author shows countries, institutions and organizations that study this problem, as well as funds financing them; names productive periodicals and authors with high publication activity; presents monographs and dissertation studies of recent years; reveals the main research areas.

Search filters and the systematization of documents in both DCs makes it easy to find relevant documents on a topic that can form the basis for further research, as bibliographic materials can be obtained from any computer. Full texts of publications from WoS are possible either for a fee, or on a license agreement (except for Open Access publications). Regional Arctic safety materials from DB Scholar Sibirica of SPSL SB RAS are free, available on the library website www.spsl.nsc.ru (options "Catalogs and Databases" $\rightarrow$ "Bibliographic Databases" $\rightarrow$ "Scholar Sibirica"), where all e-documents are provided with hyperlinks from a bibliographic record to a paper full, publications with DOI provide a link to the publisher's website or to the work itself. All printed documents are stored in the library, they can be obtained by the interlibrary loan or in the reading rooms of the library. Besides, a user can order a full-text cope of any document on the library homepage (option "On-line order of e-article").

\section{References}

1. Ukaz Prezidenta RF ot 05.03.2020 № 164 “Ob Osnovakh gosudarstvennoy politiki Rossiyskoy Federatsii v Arktike na period do 2035 goda" 
[Decree of the President of the Russian Federation on 05.03.2020 No. 164 "On the State Policy Bases of the Russian Federation in the Arctic for the Period until 2035"]. Garant.ru. URL: https://www.garant.ru/ products/ipo/prime/doc/73606526/ (accessed 10.05.2020).

2. Lavrik O.L., Busygina T.V., Rykova V.V. Slavic \& East European Information Resources, 2015, vol. 16, no 1/2, pp. 13-21. DOI: 10.1080/ 15228886.2015.1016866

3. Busygina T.V., Rykova V.V. DESIDOC Journal of Library \& Information Technology, 2019, vol. 39, no 4, pp. 152-161. DOI: 10.14429/ djlit.39.4.14454

4. Busygina, T., Rykova, V. Environmental Science and Pollution Research, 2020, vol. 27, no 19, pp. 23490-23502. DOI: https://doi. org/10.1007/s11356-020-08717-0.

5. Nord D. (ed.) Leader ship for the North: the influence and impact of Arctic Council chair. Cham: Springer, 2019. 201 p.

6. Tynkkynen V.-P., Tabata Sh., Gritsenko D., Goto V. (eds.) Russia's Far North: the contested energy frontiers. London: Routledge, 2019. 252 p.

7. Ivchenko B.P., Shamakhov V.A. Obespecheniye natsional'noy bezopasnosti $v$ Arkticheskoy zone Rossiyskoy Federatsii [National security provision in the Arctic zone of the Russian Federation]. Saint Petersburg, 2019. $156 \mathrm{p}$.

\section{Список литературы}

1. Указ Президента РФ от 05.03.2020 № 164 «Об Основах государственной политики Российской Федерации в Арктике на период до 2035 года» // Гарант.ru. URL: https://www.garant.ru/products/ipo/ prime/doc/73606526/ (дата обращения: 10.05.2020).

2. Lavrik O.L., Busygina T.V., Rykova V.V. Information resources generated by the largest library in Siberia to support multidisciplinary research // Slavic \& East European Information Resources. 2015. Vol. 16, № 1/2. P. 13-21. DOI: 10.1080/15228886.2015.1016866

3. Busygina T.V., Rykova V.V. Scientometric visualisation of the documentary array on Semipalatinsk nuclear test site // DESIDOC Journal of Library \& Information Technology. 2019. Vol. 39, № 4. P. 152-161. DOI: $10.14429 /$ djlit.39.4.14454 
4. Busygina T., Rykova V. Scientometric analysis and mapping of documentary array on the issue "Oil and petroleum products in soil and groundwater" // Environmental Science and Pollution Research. 2020. Vol. 27, № 19. P. 23490-23502. DOI: https://doi.org/10.1007/s11356020-08717-0

5. Nord D. (ed.) Leader ship for the North: the influence and impact of Arctic Council chair. Cham: Springer, 2019. 201 p.

6. Tynkkynen V.-P., Tabata Sh., Gritsenko D., Goto V. (eds.) Russia's Far North: the contested energy frontiers. London: Routledge, 2019. $252 \mathrm{p}$.

7. Ивченко Б.П., Шамахов В.А. Обеспечение национальной безопасности в Арктической зоне Российской Федерации. Санкт-Петербург, 2019. 156 с.

\section{DATA ABOUT THE AUTHOR}

Rykova Valentina Viktorovna, Senior Researcher of the Department of Scientific Bibliography

State Public Scientific Technological Library of the Siberian Branch of the Russian Academy of Sciences

15, Voskhod Str., Novosibirsk, 630200, Russian Federation

rykova@gpntbsib.ru

SPIN-code: 4051-1041

ORCID: 0000-0002-3205-7461

Researcher ID: I-9710-2018

Scopus Author ID: 56682712200

\section{ДАННЫЕ ОБ АВТОРЕ}

Рыкова Валентина Викторовна, старший научный сотрудник Отдела научной библиографии

Государственная публичная научно-техническая библиотека Сибирского отделения Российской академии наук (ГПНТБ СО РАН)

ул. Восход, 15, г. Новосибирск, 630200, Российская Федерация rykova@gpntbsib.ru 